\title{
New Sources of Resistance in Sorghum (Sorghum bicolor) Germplasm Are Effective Against a Diverse Array of Potyvirus spp.
}

Dallas L. Seifers, Professor, and Ramasamy Perumal, Assistant Professor, Kansas State University, Agricultural Research CenterHays, Hays 67601-9228; and Christopher R. Little, Assistant Professor, Department of Plant Pathology, Kansas State University, Manhattan 66506

\begin{abstract}
Seifers, D. L., Perumal, R., and Little, C. R. 2012. New sources of resistance in sorghum (Sorghum bicolor) germplasm are effective against a diverse array of Potyvirus spp. Plant Dis. 96:1775-1779.

Sorghum is a host to numerous Potyvirus spp. and its germplasm encompasses a wide range of infection responses to these viruses. We determined how 183 mini-core-collection sorghum germplasm accessions responded to mechanical inoculation with Maize dwarf mosaic virus (MDMV) in growth regimes in which they were maintained at $30^{\circ} \mathrm{C}$ followed by $16^{\circ} \mathrm{C}$ for 5 days. Accessions that appeared immune to MDMV in this initial screening were evaluated for their response in a similar temperature maintenance regime to mechanical inoculation with MDMV, Sugarcane mosaic virus strain MDB (SCMV-MDB), Sorghum mosaic virus (SrMV), Zea mosaic virus (ZeMV), and Kansas,

Nigerian, and Australian isolates of Johnsongrass mosaic virus (JGMV-KS, -N, and -Aus, respectively). In both experiments, MDMV systemically infected all accessions except international sorghum accession number (IS) 7679 and IS 20740. These accessions also proved resistant to MDMV, SCMV-MDB, SrMV, and JGMV-N but both were susceptible to the JGMV-KS and JGMV-Aus isolates. IS 7679 but not IS 20740 was resistant to infection with ZeMV. These observations suggest that IS 7679 and IS 20740 might serve as new sources of resistance to several Potyvirus spp. that systemically infect sorghum.
\end{abstract}

Sorghum (Sorghum bicolor (L.) Moench) is a host to several virus species of the family Potyviridae, including Maize dwarf mosaic virus (MDMV) (formerly MDMV-A), Sugarcane mosaic virus strain MDB (SCMV-MDV; formerly MDMV-B), Johnsongrass mosaic virus (JGMV), Sorghum mosaic virus (SrMV), and Zea mosaic virus (ZeMV). Of these, MDMV and SCMV-MDB are most often associated with the disease called maize dwarf mosaic of corn and sorghum $(21,22)$. JGMV has also been documented to naturally infect sorghum in the United States $(14,17)$. A few instances of natural infection of sorghum with SrMV in Texas have been reported (9), and ZeMV occurs in Israel, where it infects maize and sorghum (18).

Maize dwarf mosaic of sorghum has been recognized as an important disease of sorghum in the United States (22). Two principal vectors of MDMV and SCMV-MDB are the corn leaf aphid, Rhopalosiphum maidis (Fitch), and the greenbug, Schizaphis graminum Rond. (4,7). At warm temperatures, sorghum plants respond initially to infection with mosaic symptoms but produce a red-leaf symptom when they are exposed to cooler temperatures of about $16^{\circ} \mathrm{C}(12,21)$. This symptom is a consequence of the necrosis induced by infection. The term "red-leaf" is also applied to sorghum genotypes that produce tan pigments during necrosis (10). In earlier literature, the mosaic reaction was described as a "resistant" response (8), although it demonstrated susceptibility to systemic virus infection. Other authors have described this "mosaic-only" response to infection at different temperatures as resistance, "tolerance", or as a reaction following infection that should be preferred when screening germplasm $(3,5,10,22)$. Sorghum that respond to MDMV exclusively with mosaic symptoms have been shown to

Corresponding author: D. L. Seifers, E-mail: dseifers@ksu.edu

This research has been assigned contribution number 12-333-J from the Kansas Agricultural Experiment Station.

Accepted for publication 12 June 2012.

http://dx.doi.org/10.1094/PDIS-03-12-0224-RE

(C) 2012 The American Phytopathological Society suffer less yield loss when infected, ranging from $31.4 \%$ for ' $\mathrm{Tx}$ 412', to no loss of yield for 'Tx 414', while 'CK-60', which develops necrosis, experienced a $47.6 \%$ yield loss (5). By contrast, yield reductions of sorghum infected with SCMV-MDB were least severe for those with only mosaic and most severe in lines with redleaf symptoms (1).

Genetic resistance in sorghum to MDMV has been historically derived from 'Krish'. In this photoperiod-sensitive forage sorghum cultivar from India, resistance is controlled by a single dominant gene designated 'Krish' (13). In Australia, the Krish gene was also found to confer resistance to systemic infection with JGMV (19), although it is ineffective against the JGMV-Kr strain (15). The Krish gene also protects sorghum from systemic infection with SCMV-MDB (10). Another breeding resource is 'Wiru' (international sorghum accession number [IS] 8789), a photoperiod-sensitive tall sorghum line which has been found to be immune to mechanical inoculation with MDMV and SCMV-MDB (10). Because germplasm with claims to resistance should confer protection in the setting in which it is intended to be grown, sources with resistance should be characterized regarding the mode of virus transmission. For example, the Nigerian grain sorghum line 'Q7539' was observed in Australia to resist natural infection with JGMV (15) but proved susceptible to systemic infection by mechanical inoculation (11). The resistance of the Q7539 line, unlike the monogenic dominant inheritance of Krish, is complexly inherited (11). Q7539 has also been shown to be resistant to MDMV in Texas (20).

In both of two mechanical inoculation tests of 183 mini-corecollection sorghum accessions (23) with a Kansas isolate of MDMV, two accessions failed to become systemically infected. This apparent immunity was also observed in subsequent experiments when IS 7679 and IS 20740 (tall with lax type panicle and photoperiod sensitive) were tested with MDMV and other Potyvirus spp. This study reports the results of systematic examinations of how these two sorghum accessions responded to mechanical inoculation with MDMV, SCMV-MDB, JGMV, SrMV, and ZeMV and advances the case for their use as sources of Potyvirus spp. resistance.

\section{Materials and Methods}

Virus source and maintenance. A Kansas isolate of MDMV (formerly MDMV-A) was used in the present study (16). The Ne- 
braska source of SCMV-MDB (formerly MDMV-B) was obtained from Stan Jensen (University of Nebraska, Lincoln), and the ZeMV isolate was the original used in 2000 to describe the virus (18). Three isolates of JGMV were used: a Kansas isolate (JGMVKS) (17); the Nigerian isolate of JGMV (JGMV-N), which was used to describe the virus (17); and the Australian isolate (JGMVAus, obtained from Dennis Persley, Indooroopilly, Australia) that infects sorghum with the Krish gene for resistance $(11,15)$. The PV 51 isolate of SrMV was obtained from the American Type Culture Collection (2). All isolates were increased in 'GA TE 76' sorghum in growth chambers (Percival Model PGC-15 WC) set at $30^{\circ} \mathrm{C}$ with a 12-h photoperiod of fluorescent light $\left(250 \mu \mathrm{Es}^{-1} \mathrm{~m}^{-2}\right)$. Symptomatic GA TE 76 sorghum plants separately infected with each virus were harvested separately at 21 days post inoculation (DPI) and frozen at $-80^{\circ} \mathrm{C}$ just prior to the start of these studies. All inoculations of the seedlings in the experiments were conducted using the 21 DPI frozen virus sources. GA TE 76 sorghum was used because it is susceptible to systemic infection with all the Potyvirus spp. examined in this study (D. L. Seifers, unpublished).

Indirect enzyme-linked immunosorbent assay and sources of antiserum. The third leaves from the base of individual plants were sampled separately at 14 DPI. Each leaf sample was ground in a $1.5-\mathrm{ml}$ microcentrifuge tube with a wood applicator stick (Fisher Scientific) at a 1:30 (wt/vol) dilution in $0.05 \mathrm{M}$ carbonate buffer, pH 9.6 (6). Extracts $(200 \mu \mathrm{l})$ were pipetted into wells of enzyme-linked immunosorbent assay (ELISA) plates (Immulon 1; Fisher Scientific) for $1 \mathrm{~h}$ at $37^{\circ} \mathrm{C}$. Following a rinse step, the wells were incubated for $1 \mathrm{~h}$ at $37^{\circ} \mathrm{C}$ with the appropriate antivirus antibody $(200 \mu \mathrm{l})$ in dilution buffer $(6)$. The wells were rinsed and blocked for $1 \mathrm{~h}$ in blocking buffer (5\% nonfat dry milk, $0.01 \%$ antifoam $\mathrm{A}$, and $0.02 \%$ sodium azide in phosphate-buffered saline, $\mathrm{pH} \mathrm{7.4)}$ at $37^{\circ} \mathrm{C}$. After blocking, $200 \mu \mathrm{l}$ of anti-rabbit antibody/alkaline phosphatase conjugate (Southern Biotechnology Associates) in dilution buffer $(1: 3,000 \mathrm{vol} / \mathrm{vol})$ was added to each well. The plates were held at $37^{\circ} \mathrm{C}$ for $1 \mathrm{~h}$. The wells were rinsed, and $200 \mu \mathrm{l}$ of p-nitrophenyl phosphate substrate $(0.714 \mathrm{mg} / \mathrm{ml})$, in substrate buffer (6) was added to each well. The plates were then held at 20 to $22^{\circ} \mathrm{C}$ for $30 \mathrm{~min}$. Absorbance at $405 \mathrm{~nm}$ was measured using an iMark plate reader (Bio-Rad Laboratories). Absorbance values were arbitrarily considered positive if they were at least twice those of the equivalent mock-inoculated control value. Plants below the arbitrary threshold were considered negative in ELISA. The terms "positive" and "negative" are used for the purposes of brevity; rather than repeatedly stating that extracts from plants reacted with a given antibody set at a two times or greater than the healthy control, we state that such a plant or plants were positive and a plant or plants below the arbitrary threshold are negative.

The MDMV antiserum (PVAS 55) was obtained from the American Type Culture Collection and the ZeMV antiserum was obtained as previously described (18). A single antiserum prepared to a Kansas isolate as previously described was used for analyses of all JGMV isolates (17). The SCMV-MDB antiserum was from Ray Louie (United States Department of Agriculture-Agricultural Research Service, Wooster, $\mathrm{OH}$ ) and the SrMV antiserum was from K.-B. G. Scholthof (Texas A\&M, University, College Station). The MDMV, JGMV, SrMV, and ZeMV antisera were used at a 1:1,000 (vol/vol) dilutions and the SCMV-MDB antiserum at a 1:400 (vol/vol) dilution. The dilution for each antiserum was prepared from a stock solution of protein at $1 \mathrm{mg} / \mathrm{ml}$ (absorbance at $280 \mathrm{~nm}=1.4$ ).

Evaluating host responses in different temperature regimes. The 183 mini-core-collection accessions were analyzed in two sets in each of two experiments due to limited growth chamber space. The seed of each line were planted in separate rows in soil-filled (Harney clay loam soil, fine montmorillonitic, mesic type Argiustoll) flats ( 30 by $50 \mathrm{~cm}$ ) with 14 rows each divided in half, so that 28 rows $(150$ by $35 \mathrm{~mm})$ were available. The plants were maintained in a greenhouse for 7 days until the two-leaf growth stage. The plants were mechanically inoculated using a DeVilbiss
Table 1. Sorghum accessions that developed only a mosaic symptoms 19 days after mechanical inoculation with Maize dwarf mosaic virus in a growth chamber ${ }^{\mathrm{a}}$

\begin{tabular}{|c|c|c|}
\hline IS number & Country $^{b}$ & Phenotype $^{\mathrm{c}}$ \\
\hline 608 & United States & M2 \\
\hline 995 & United States & $\mathrm{M} 2$ \\
\hline 1041 & India & $\mathrm{M} 2$ \\
\hline 1212 & China & $\mathrm{M} 2$ \\
\hline 1219 & China & $\mathrm{M} 2$ \\
\hline 2205 & India & M2 \\
\hline 2382 & South Africa & M2 \\
\hline 2397 & South Africa & $\mathrm{M} 2$ \\
\hline 2864 & South Africa & $\mathrm{M} 2$ \\
\hline 2872 & Egypt & $\mathrm{M} 2$ \\
\hline 3121 & United States & $\mathrm{M} 2$ \\
\hline 3971 & India & M2 \\
\hline 4360 & India & M2 \\
\hline 4515 & India & M2 \\
\hline 4613 & India & $\mathrm{M} 2$ \\
\hline 4631 & India & M2 \\
\hline 4698 & India & $\mathrm{M} 2$ \\
\hline 5094 & India & M2 \\
\hline 5386 & India & M2 \\
\hline 5529 & India & $\mathrm{M} 2$ \\
\hline 5667 & India & M2 \\
\hline 5919 & India & $\mathrm{M} 2$ \\
\hline 5999 & India & $\mathrm{M} 2$ \\
\hline 6351 & India & M2 \\
\hline 6354 & India & M2 \\
\hline 6421 & India & M2 \\
\hline 8012 & Japan & M2 \\
\hline 8348 & Pakistan & $\mathrm{M} 2$ \\
\hline 8777 & Uganda & M2 \\
\hline 8916 & Uganda & M2 \\
\hline 9108 & Kenya & M2 \\
\hline 9745 & Sudan & M2 \\
\hline 9830 & Sudan & $\mathrm{M} 2$ \\
\hline 10302 & Thailand & M2 \\
\hline 10867 & Chad & $\mathrm{M} 2$ \\
\hline 10969 & United States & $\mathrm{M} 2$ \\
\hline 11026 & Ethiopia & M2 \\
\hline 11619 & Ethiopia & M2 \\
\hline 11919 & Ethiopia & M2 \\
\hline 12447 & Sudan & M2 \\
\hline 12706 & United States & $\mathrm{M} 2$ \\
\hline 12735 & Saudi Arabia & M2 \\
\hline 12804 & Turkey & M2 \\
\hline 12883 & India & M2 \\
\hline 12937 & Ethiopia & M2 \\
\hline 13294 & Venezuela & $\mathrm{M} 2$ \\
\hline 13549 & Mexico & $\mathrm{M} 2$ \\
\hline 14010 & South Africa & $\mathrm{M} 2$ \\
\hline 14090 & Argentina & M2 \\
\hline 14290 & Botswana & M2 \\
\hline 15466 & Cameroon & M2 \\
\hline 15478 & Cameroon & $\mathrm{M} 2$ \\
\hline 15931 & Cameroon & $\mathrm{M} 2$ \\
\hline 15945 & Cameroon & M2 \\
\hline 16382 & Cameroon & M2 \\
\hline 17941 & India & M2 \\
\hline 18039 & India & $\mathrm{M} 2$ \\
\hline 19153 & Sudan & M2 \\
\hline 19445 & Botswana & $\mathrm{M} 2$ \\
\hline 19450 & Botswana & $\mathrm{M} 2$ \\
\hline 19975 & Senegal & M2 \\
\hline 20298 & Niger & M2 \\
\hline
\end{tabular}

(continued on next page)

a IS = International sorghum accession numbers are as given by Upadhyaya et al. (23).

${ }^{b}$ Country of origin of the sorghum is as given by Upadhyaya et al. (23).

c Phenotype: $\mathrm{M} 1$ = faint mosaic, $\mathrm{M} 2=$ moderate mosaic, $\mathrm{M} 3$ = severe mosaic, $\mathrm{N} 1=$ necrotic spots and dashes (1 to $10 \%$ of the leaf), $\mathrm{N} 2=$ necrotic streaks and stripes ( 11 to $40 \%$ of the leaf), N3 = whole leaf necrosis (41 to $100 \%$ of the leaf), and NS = no symptoms. Following inoculation, the plants were held at $30^{\circ} \mathrm{C}$ for 14 days followed by 5 days at $16^{\circ} \mathrm{C}$. 
Table 1. (continued from preceding page)

\begin{tabular}{|c|c|c|}
\hline IS number & Country $^{b}$ & Phenotype $^{c}$ \\
\hline 20679 & United States & M2 \\
\hline 20697 & United States & M2 \\
\hline 20713 & United States & M2 \\
\hline 20767 & United States & M2 \\
\hline 20816 & United States & M2 \\
\hline 20956 & India & M2 \\
\hline 21083 & Kenya & M2 \\
\hline 21425 & Malawi & M2 \\
\hline 21512 & Malawi & M2 \\
\hline 22294 & Botswana & M2 \\
\hline 22609 & Sri Lanka & M2 \\
\hline 22616 & Myanmar & M2 \\
\hline 22720 & Somalia & M2 \\
\hline 23216 & Zambia & M2 \\
\hline 23514 & Ethiopia & M2 \\
\hline 23579 & Ethiopia & M2 \\
\hline 23586 & Ethiopia & M2 \\
\hline 23590 & Ethiopia & M2 \\
\hline 23644 & Gambia & M2 \\
\hline 23684 & Mozambique & M2 \\
\hline 23891 & Republic of Yemen & M2 \\
\hline 24463 & South Africa & M2 \\
\hline 24503 & South Africa & M2 \\
\hline 25249 & Ethiopia & M2 \\
\hline 25301 & Ethiopia & M2 \\
\hline 25548 & Rwanda & M2 \\
\hline 25732 & Mali & M2 \\
\hline 25836 & Mali & M2 \\
\hline 25910 & Mali & M2 \\
\hline 25981 & Mali & M2 \\
\hline 25989 & Mali & M2 \\
\hline 26025 & Mali & M2 \\
\hline 26046 & Mali & M2 \\
\hline 26222 & Togo & M2 \\
\hline 26617 & Madagascar & M2 \\
\hline 26694 & South Africa & M2 \\
\hline 26701 & South Africa & M2 \\
\hline 27557 & Burkina Faso & M2 \\
\hline 27697 & Sierra Leone & M2 \\
\hline 27786 & Morocco & M2 \\
\hline 27887 & South Africa & M2 \\
\hline 28141 & Republic of Yemen & M2 \\
\hline 28313 & Republic of Yemen & M2 \\
\hline 28389 & Republic of Yemen & M2 \\
\hline 28449 & Republic of Yemen & M2 \\
\hline 28451 & Republic of Yemen & M2 \\
\hline 28614 & Republic of Yemen & M2 \\
\hline 29091 & Republic of Yemen & M2 \\
\hline 29100 & Republic of Yemen & M2 \\
\hline 29187 & Swaziland & M2 \\
\hline 29241 & Swaziland & M2 \\
\hline 29304 & Swaziland & M2 \\
\hline 29314 & Swaziland & M2 \\
\hline 29358 & Lesotho & M2 \\
\hline 29441 & Lesotho & M2 \\
\hline 29468 & Lesotho & M2 \\
\hline 29519 & Lesotho & M2 \\
\hline 29627 & South Africa & M2 \\
\hline 29654 & China & M2 \\
\hline 29689 & Zimbabwe & M2 \\
\hline 29714 & Zimbabwe & M2 \\
\hline 29733 & Zimbabwe & M2 \\
\hline 29914 & Zimbabwe & M2 \\
\hline 30079 & Zimbabwe & M2 \\
\hline 30231 & Zimbabwe & M2 \\
\hline 30383 & China & M2 \\
\hline 30400 & China & M2 \\
\hline 30451 & China & M2 \\
\hline 30460 & China & M2 \\
\hline 30507 & Republic of Korea & M2 \\
\hline 30508 & Republic of Korea & M2 \\
\hline 30533 & Republic of Korea & M2 \\
\hline 30536 & Republic of Korea & M2 \\
\hline
\end{tabular}

(continued in next column)
Table 1. (continued from preceding column)

\begin{tabular}{llc}
\hline IS number & \multicolumn{1}{c}{ Country $^{\mathbf{b}}$} & Phenotype $^{\mathbf{c}}$ \\
\hline 30562 & Republic of Korea & M2 \\
30572 & Cameroon & M2 \\
31299 & Uganda & M2 \\
31706 & Republic of Yemen & M2 \\
31714 & Republic of Yemen & M2 \\
32245 & Republic of Yemen & M2 \\
32295 & India & M2 \\
32349 & India & M2 \\
32787 & Somalia & M2 \\
33353 & Kenya & M2 \\
33844 & India & M2 \\
\hline
\end{tabular}

Number 152 atomizer $\left(4.2 \mathrm{~kg} / \mathrm{cm}^{2}\right.$ air pressure) on both leaves with a 1:20 (wt/vol) dilution of extract prepared from a frozen stock of GA TE76 sorghum infected with the MDMV-KS isolate. The inoculated plants were held in a growth chamber (Percival Model PGC-15WC) set at $30^{\circ} \mathrm{C}$ with a 10 -h photoperiod under fluorescent light $\left(250 \mu \mathrm{Es}^{-1} \mathrm{~m}^{-2}\right)$. The plants were rated at 14 days DPI for symptom phenotype as follows: $\mathrm{M} 1=$ faint mosaic, $\mathrm{M} 2=$ moderate mosaic, $\mathrm{M} 3$ = severe mosaic, $\mathrm{N} 1=$ necrotic spots and dashes $(1$ to $10 \%$ of the leaf), $\mathrm{N} 2=$ necrotic streaks and stripes ( 11 to $40 \%$ of the leaf), $\mathrm{N} 3$ = whole leaf necrosis (41 to $100 \%$ of the leaf), and $\mathrm{NS}=$ no symptoms. Immediately following this rating, the temperature in the chamber was reduced to $16^{\circ} \mathrm{C}$ and the plants were rated for symptom type 5 days later at 19 DPI. On the same day as the final rating, the remaining accessions were inoculated as described above and held in the same chamber at $30^{\circ} \mathrm{C}$, and the process was repeated. The experiment was repeated. The number of plants in the two experiments for each line varied from 6 to 14 . Sorghum line 'KS83' and GA TE 76 served as controls, each inoculated with MDMV. When exposed to $16^{\circ} \mathrm{C}$ for 5 days, the former develops leaf necrosis and the latter mosaic symptoms only (D. L. Seifers, unpublished).

Response of sorghum accessions IS 7679 and IS 20740 to different Potyvirus spp. Metal $(30$ by $50 \mathrm{~cm}$ ) flats that were filled with a Harney clay loam soil (soil as described above) having 28 rows were prepared. On three consecutive days, seed of IS 7679, IS 20740, GA TE 76, and 'ICI 5616' were planted into four separate rows constituting a set and the same set was planted seven times in the flat, creating a total of 28 rows. Following each planting, the flats were held in a growth chamber (Percival Model PGC-15WC) at $30^{\circ} \mathrm{C}$ with a 10 -h photoperiod under fluorescent light $\left(250 \mu \mathrm{Es}^{-1}\right.$ $\mathrm{m}^{-2}$ ). When plants were at the two-leaf growth stage, plants in each of the seven sets were mechanically (finger-rub) inoculated separately with a 1:10 (wt/vol) extract of the appropriate virus prepared from GA TE 76 inoculated 14 days earlier with the respective virus. The seven viruses used in this study were MDMV-KS, SCMVMDB, PV 51 isolate of SrMV, ZeMV, JGMV-KS, JGMV-N, and JGMV-Aus. The experiment was repeated two more times on consecutive days. The plants in each of the three experiments were held in the same growth chamber at $30^{\circ} \mathrm{C}$ under the same lighting conditions as described above. The plants were rated for symptoms at 14 DPI followed by sampling of the third leaf of each plant individually and processed for analysis in ELISA as described above. The virus controls were sorghum GA TE 76, which is susceptible to all viruses used in this study, and ICI 5616, which is systemically infected by the JGMV-Aus virus isolate (D. L. Seifers, unpublished).

\section{Results}

Evaluation of phenotypes maintained in different temperature regimes. Examination of the 183 mini-core-collection accessions after inoculation with MDMV showed that they expressed a diverse range of disease phenotypes (Tables 1, 2, and 3). Of the 183 accessions, 146 had plants that developed only mosaic symptoms (Table 1). Sixteen IS accessions had plants which developed necrosis (Table 2). Interestingly, 19 accessions had plants that did 
Table 2. Sorghum accessions that developed necrosis 19 days after mechanical inoculation with Maize dwarf mosaic virus in a growth chamber ${ }^{\mathrm{a}}$

\begin{tabular}{llc}
\hline IS number & Country $^{\mathbf{b}}$ & Phenotype $^{\mathbf{c}}$ \\
\hline 1233 & China & M2N1 \\
2389 & South Africa & M2N3 \\
2413 & Iran & M2N2 \\
2426 & Afghanistan & M2N3 \\
3158 & South Africa & M2N3 \\
7310 & Nigeria & M2N2 \\
9177 & Kenya & M2N3 \\
13782 & South Africa & M2N3 \\
13893 & South Africa & M2N2 \\
20762 & United States & M2N2 \\
22986 & Sudan & M2N2 \\
24462 & South Africa & M2N3 \\
24953 & Zambia & M2N1 \\
26749 & South Africa & M2N2 \\
29335 & Swaziland & M2N1 \\
29582 & Lesotho & M2N2 \\
\hline
\end{tabular}

a IS = International sorghum accession numbers are as given by Upadhyaya et al. (23).

${ }^{b}$ Country of origin of the sorghum is as given by Upadhyaya et al. (23).

${ }^{\mathrm{c}}$ Phenotype: $\mathrm{M} 1=$ faint mosaic, $\mathrm{M} 2=$ moderate mosaic, $\mathrm{M} 3=$ severe mosaic, $\mathrm{N} 1=$ necrotic spots and dashes ( 1 to $10 \%$ of the leaf), $\mathrm{N} 2=$ necrotic streaks and stripes (11 to $40 \%$ of the leaf), N3 = whole leaf necrosis (41 to $100 \%$ of the leaf), and NS = no symptoms. Following inoculation, the plants were held at $30^{\circ} \mathrm{C}$ for 14 days followed by 5 days at $16^{\circ} \mathrm{C}$. Plants of these lines developed necrosis after exposure to $16^{\circ} \mathrm{C}$.

not express uniform phenotypes but encompassed individuals whose symptoms were exclusively of the mosaic type and others that developed necrosis (Table 3). The accessions IS 7679 and IS 20740 differed from all others by uniformly failing to develop symptoms in both experiments.

Responses of IS 7679 and IS 20740 to inoculation with a diverse array of Potyvirus spp. Plants of the accessions inoculated with the seven viruses were differentially infected depending upon isolate (Table 4). All GA TE 76 plants were systemically infected when inoculated with each virus isolate. Plants of accession IS 7679 were systemically infected with JGMV-KS and JGMV-Aus; those of IS 20740 with ZeMV, JGMV-KS, and JGMV-Aus; and those of ICI 5616 with only the JGMV-Aus isolate. In the three experiments, only symptomatic plants reacted with their respective homologous antibody, indicating that immunity, rather than latent infection, accounted for the absence of symptoms.

\section{Discussion}

The mini-core collection of sorghum accessions represents $1 \%$ of a core collection of 2,247 sorghum accessions that are representative of the species diversity in sorghum (23). In the initial experiment in which we analyzed the responses of 183 mini-corecollection accessions to inoculation with MDMV, the diverse array of host responses (Tables 1, 2, and 3) encompassed a subset of accessions (8\%) which developed some level of necrosis and a much larger subset (79\%), which developed only a mosaic symptom in a $16^{\circ} \mathrm{C}$ maintenance regime. If we had failed to discover the resistance expressed by accessions IS 7679 and IS 20740, convention would have led us to advance the numerous accessions that responded with mosaic symptoms, because the mosaic reaction has been considered the resistant, tolerant, or preferred reaction to infection $(1,3,5,10,22)$. This preference, however, has lessened since sorghum with higher levels of resistance such as Krish, Q7539, and Wiru (IS 8789) have been identified (10,13,15). We do not know why plants in 19 of the accessions had a variable response, with some individuals developing only mosaic symptoms while others developed mosaic combined with necrosis (Table 3). This variation in phenotype may be because the accessions were not genetically homogenous.

The accessions IS 7679 and IS 20740 distinguished themselves from all others by consistently failing to develop symptoms in both experiments in which the response to MDMV was used to identify
Table 3. Sorghum accessions with mixed disease phenotypes 19 days after mechanical inoculation with Maize dwarf mosaic virus in a growth chamber $^{\mathrm{a}}$

\begin{tabular}{lll}
\hline IS number & \multicolumn{1}{c}{ Country $^{\mathbf{b}}$} & Phenotype $^{\mathbf{c}}$ \\
\hline 7305 & Nigeria & M3 \& M3N1 \\
8774 & South Africa & M2 \& M2N1 \\
12697 & Australia & M3 \& M3N1 \\
12945 & Nicaragua & M3 \& M3N2 \\
12965 & Cuba & M2 \& M2N2 \\
15170 & Cameroon & M2 \& M2N2 \\
19389 & Bangladesh & M3 \& M3N1 \\
20632 & United States & M3 \& M3N1 \\
21863 & Syrian Arab Republic & M3 \& M3N1 \\
24453 & South Africa & M3 \& M3N1 \\
24492 & South Africa & M3 \& M3N2 \\
26737 & South Africa & M3 \& M3N3 \\
29239 & Swaziland & M3 \& M3N3 \\
29326 & Swaziland & M3 \& M3N1 \\
29392 & Lesotho & M2 \& M2N2 \\
30450 & China & M2 \& M2N2 \\
30466 & China & M2 \& M2N1 \\
30838 & Cameroon & M2 \& M2N1 \\
31043 & Uganda & M3 \& M3N1 \\
\hline
\end{tabular}

${ }^{a}$ IS = International sorghum accession numbers are as given by Upadhyaya et al. (23).

${ }^{\mathrm{b}}$ Country of origin of the sorghum is as given by Upadhyaya et al. (23).

${ }^{\mathrm{c}}$ Phenotype: $\mathrm{M} 1$ = faint mosaic, $\mathrm{M} 2=$ moderate mosaic, $\mathrm{M} 3=$ severe mosaic, $\mathrm{N} 1=$ necrotic spots and dashes ( 1 to $10 \%$ of the leaf), $\mathrm{N} 2=$ necrotic streaks and stripes ( 11 to $40 \%$ of the leaf), N3 = whole leaf necrosis (41 to $100 \%$ of the leaf), and NS = no symptoms. Following inoculation, the plants were held at $30^{\circ} \mathrm{C}$ for 14 days followed by 5 days at $16^{\circ} \mathrm{C}$.

candidates for resistant host responses to other Potyvirus spp. The question of the sources or sources of the apparent resistance needs to be addressed. We considered the possibility that IS 7679 and IS 20740, like Krish, are photoperiod sensitive (R. Perumal, personal communication) and might have derived their resistance from that source by crossing. This uncertainty prompted us to conduct an extended analysis of the IS 7679 and IS 20740 accessions at $30^{\circ} \mathrm{C}$ by separately inoculating with MDMV, SCMV-MDB, SrMV, ZeMV, and JGMV-KS, JGMV-N, and JGMV-Aus.

Different phenotypic responses to infection were observed for the IS 7679 and IS 20740 accessions depending on the inoculated virus (Table 4). The source of Potyvirus spp. resistance in ICI 5616 is unknown but it is assumed that Krish is the source because it is susceptible to only the JGMV-Aus isolate. In our previous studies, we have shown that QL20, a Krish source of resistance (11), was resistant to all but the JGMV-Aus virus isolate (D. L. Seifers, unpublished). Interestingly, the IS 7679 and IS 20740 accessions were not susceptible to infection with the Nigerian isolate of JGMV but were susceptible to the Kansas and Australian isolates of JGMV. Another difference between the JGMV-KS and the JGMV-N isolates is that the Nigerian isolate does not infect johnsongrass or oat, whereas JGMV-KS infects both species and neither isolate infects QL3 sorghum (17; D. L. Seifers, unpublished). Further characterization of the resistance in the two accessions was obtained using the ZeMV isolate that systemically infected IS 20740 but not IS 7679, indicating that the two sources of resistance are not identical. Sorghum GA TE 76 responded with systemic symptoms to inoculation with each of the tested Potyvirus spp., which is consistent with previous work (D. L. Seifers, unpublished). Taken together, these data are most consistent with the resistance conferred by IS 7679 or IS 20420 not being a Krish source.

In addition to providing sources of resistance to MDMV, the IS 7679 and IS 20470 accessions may well serve as effective new sources of resistance to other Potyvirus spp., including SCMVMDB and SrMV. For IS 7679, resistance extends to ZeMV as well. These two sources do not confer resistance to all the isolates of JGMV we tested, and variant isolates of other viruses yet to be tested might also attenuate the case we make here for their versatil- 
Table 4. Enzyme-linked immunosorbent assay (ELISA) values and numbers of infected sorghum plants mechanically inoculated with different Potyvirus spp. after being held in a growth chamber at $30^{\circ} \mathrm{C}$ for 14 days ${ }^{\mathrm{a}}$

\begin{tabular}{|c|c|c|c|c|c|c|c|c|c|c|}
\hline \multirow[b]{2}{*}{ Virus $^{c}$} & \multicolumn{10}{|c|}{ Sorghum entry and number of plants $(N)$ analyzed for each entry ${ }^{b}$} \\
\hline & $N$ & IS 7679 & $N$ & IS 20740 & $N$ & ICI 5616 & $N$ & GA TE 76 & $N$ & Healthy \\
\hline \multirow[t]{2}{*}{ MDMV } & $0 / 15$ & 0.005 & & 0.004 & & 0.004 & & 0.445 & & 0.008 \\
\hline & & $( \pm 0.001)$ & $0 / 22$ & $( \pm 0.000)$ & $0 / 22$ & $( \pm 0.000)$ & $3 / 3$ & $( \pm 0.068)$ & $0 / 3$ & $( \pm 0.001)$ \\
\hline \multirow[t]{2}{*}{ SCMV-MDB } & $0 / 19$ & 0.005 & & 0.004 & & 0.004 & & 0.201 & & 0.013 \\
\hline & & $( \pm 0.000)$ & $0 / 22$ & $( \pm 0.001)$ & $0 / 25$ & $( \pm 0.001)$ & $3 / 3$ & $( \pm 0.043)$ & $0 / 3$ & $( \pm 0.004)$ \\
\hline \multirow[t]{2}{*}{ SrMV } & $0 / 14$ & 0.003 & & 0.003 & & 0.003 & & 0.465 & & 0.010 \\
\hline & & $( \pm 0.001)$ & $0 / 22$ & $( \pm 0.001)$ & $0 / 28$ & $( \pm 0.001)$ & $3 / 3$ & $( \pm 0.091)$ & $0 / 3$ & $( \pm 0.003)$ \\
\hline \multirow[t]{2}{*}{ ZeMV } & $0 / 14$ & 0.032 & & 0.771 & & 0.076 & & 0.955 & & 0.074 \\
\hline & & $( \pm 0.013)$ & $23 / 23$ & $( \pm 0.034)$ & $0 / 25$ & $( \pm 0.009)$ & $3 / 3$ & $( \pm 0.067)$ & $0 / 3$ & $( \pm 0.024)$ \\
\hline \multirow[t]{2}{*}{ JGMV-KS } & $13 / 13$ & 0.641 & & 0.560 & & 0.031 & & 0.667 & & 0.022 \\
\hline & & $( \pm 0.090)$ & $18 / 18$ & $( \pm 0.018)$ & $0 / 23$ & $( \pm 0.002)$ & $3 / 3$ & $( \pm 0.015)$ & $0 / 3$ & $( \pm 0.003)$ \\
\hline \multirow[t]{2}{*}{ JGMV-N } & $17 / 17$ & 0.012 & & 0.018 & & 0.016 & & 0.324 & & 0.019 \\
\hline & & $( \pm 0.003)$ & $0 / 23$ & $( \pm 0.003)$ & $0 / 27$ & $( \pm 0.003)$ & $3 / 3$ & $( \pm 0.093)$ & $0 / 3$ & $( \pm 0.003)$ \\
\hline \multirow[t]{2}{*}{ JGMV-Aus } & $13 / 13$ & 0.408 & & 0.309 & & 0.372 & & 0.383 & & 0.018 \\
\hline & & $( \pm 0.031)$ & $22 / 22$ & $( \pm 0.043)$ & $22 / 22$ & $( \pm 0.031)$ & $3 / 3$ & $( \pm 0.028)$ & $0 / 3$ & $( \pm 0.001)$ \\
\hline
\end{tabular}

${ }^{a}$ Values $(405 \mathrm{~nm})$ are the mean from three experiments followed by \pm the standard error.

b IS 7679 and IS 20740 are sorghum accessions and 'GA TE 76' and 'ICI 5616' are cultivars. Healthy = mock-inoculated GA TE 76 sorghum. For each value $\mathrm{N}$, the numerator represents the number of sorghum plants with symptoms and positive in ELISA for a respective antiserum and the denominator the total number of plants inoculated with a respective virus in the three experiments. For the GA TE 76 positive controls, a single infected plant was sampled from a set of 6 to 10 symptomatic control plants for a given virus treatment in each experiment, so that three plants were analyzed. ELISA values in bold are considered positive, indicating that virus-specific antibodies reacted with extracts from plants above the arbitrary positive threshold of twice the healthy control value. Only symptomatic plants were positive.

${ }^{\mathrm{c}} \mathrm{MDMV}=$ Maize dwarf mosaic virus, SCMV-MDB = Sugarcane mosaic virus strain maize dwarf mosaic B, SrMV = Sorghum mosaic virus, ZeMV $=$ Zea mosaic virus, $\mathrm{JGMV}=$ Johnsongrass mosaic virus $(\mathrm{KS}=\mathrm{Kansas}, \mathrm{N}=$ Nigerian, and Aus. = Australian isolates).

ity in conferring protection against a diverse array of Potyvirus spp. These findings point to a need for further studies to determine how the resistance conditioned by these accessions is inherited, and how effectively they protect yield of elite sorghum germplasm when under pressure from infection with a range of Potyvirus spp. Fresh crosses were made using IS 7679 and IS 20420 separately as donor parents with 'RTx 430', a universal adaptable sorghum susceptible to these Potyvirus spp. Evaluation of the $\mathrm{F}_{1}$ to study the gene action and subsequent segregating generations will be evaluated to develop recombinant inbred lines for marker-assisted selection to MDMV and other Potyvirus spp. resistance.

\section{Acknowledgments}

We thank J. Ackerman for his assistance in all phases of the experiments and ELISA analyses during these studies and $\mathrm{S}$. Haber for critically reading the manuscript.

\section{Literature Cited}

1. Alexander, J. D., Toler, R. W., and Giorda, L. M. 1984. Correlation of yield reductions with severities of disease symptoms in grain sorghum (Sorghum bicolor (L.) Moench) infected with sugarcane mosaic or maize dwarf mosaic viruses. (Abstr.) Phytopathology 74:794.

2. American Type Culture Collection. 1986. Catalog and Registry of the Plant Viruses. ATCC, Rockville, MD.

3. Batte, R. D., Toler, R. W., and Bockholt, A. J. 1970. Effects of time of inoculation with maize dwarf mosaic virus strain A on the agronomic characteristics of grain sorghum hybrids. (Abstr.) Phytopathology 60:581.

4. Berger, P. H., Toler, R. W., and Harris, K. F. 1983. Maize dwarf mosaic virus transmission by greenbug biotypes. Plant Dis. 67:496-497.

5. Bockholt, A. J., and Toler, R. W. 1968. Effect of maize dwarf mosaic on grain sorghum. Tex. Agric. Exp. Stn. Prog. Rep. 2509

6. Clark, M. F., and Adams, A. N. 1977. Characteristics of the microplate method of enzyme-linked immunosorbent assay for the detection of viruses. J. Gen. Virol. 34:475-483.

7. Daniels, N. E., and Toler, R. W. 1969. Transmission of maize dwarf mosaic by the greenbug, Schizaphis graminum. Plant Dis. Rep. 53:59-61.

8. Dean, J. L., and Coleman, O. H. 1959. Necrotic and resistant reactions to the sugarcane mosaic virus in sorghum. Plant Dis. Rep. 43:522-527.

9. Giorda, L. M., Toler, R. W., and Miller, F. R. 1986. Identification of sugar- cane mosaic virus strain $\mathrm{H}$ isolate in commercial grain sorghum. Plant Dis. 70:624-628.

10. Hackerott, H. L., Martin, T. J., and Harvey, T. L. 1984. Breeding for resistance to greenbug, cinch bug, and maize dwarf mosaic in sorghum. Pages 11-27 in: Proc. 38th Annu. Corn Sorghum Res. Conf.

11. Henzell, R. G., Persley, D. M., Greber, R. S., Fletcher, D. S., and Van Slobbe, L. 1982. Development of grain sorghum lines with resistance to sugarcane mosaic and other sorghum diseases. Plant Dis. 66:900-901.

12. Jarjees, M. M., and Uyemoto, J. K. 1983. Maize dwarf mosaic virus: effect of time of inoculation and symptomatology on performance of sorghum (Sorghum bicolor). Plant Dis. 67:488-489.

13. Krishnaswamy, N., Raman, V. S., and Chandrasekharam, P. 1956. An interspecific hybrid of grain sorghum and johnsongrass-S. halepense $(2 \mathrm{n}-20) \times$ S. roxburghii (2n-20). Curr. Sci. 25:195-197.

14. McDaniel, L. L., and Gordon, D. T. 1985. Identification of a new strain of maize dwarf mosaic virus. Plant Dis. 69:602-607.

15. Persley, D. M, Greber, R. S., and Henzell, R. G. 1987. Isolates of sugarcane mosaic virus-johnsongrass strain infecting Krish resistant grain sorghum genotypes in Australia. Sorghum Newsl. 30:72-73.

16. Seifers, D. L. 1984. Optimum conditions for studies with maize dwarf mosaic virus strains A and B in sorghum. Plant Dis. 68:1067-1068.

17. Seifers, D. L., Haber, S., Ens, W., She, Y.-M., Standing, K. G., and Salomon, R. 2005. Characterization of a distinct Johnsongrass mosaic virus strain isolated from sorghum in Nigeria. Arch. Virol. 150:557-576.

18. Seifers, D. L., Salomon, R., Marie-Jeanne, V., Alliot, B., Signoret, P., Haber, S., Loboda, A., Ens, W., She, Y. M., and Standing, K. 2000. Characterization of a novel potyvirus isolated from maize in Israel. Phytopathology. 90:505-513.

19. Teakle, D. S., and Pritchard, A. J. 1971. Resistance of Krish sorghum to four strains of sugarcane mosaic virus in Queensland. Plant Dis. Rep. 55:596-598.

20. Toler, R. W. 1980. Viruses and virus diseases of sorghum. Pages 395-408 in: Sorghum Diseases-A World Review. Proc. Int. Workshop Sorghum Dis. ICRISAT, Hyderabad, India.

21. Toler, R. W., and Bockholt, A. J. 1969. Maize dwarf mosaic and other currently important diseases of sorghum. In: Proc. 23rd Annu. Corn Sorghum Res. Conf. Chicago.

22. Toler, R. W., and Fredericksen, R. A. 1971. Sorghum diseases. Rep. Tex. Agric. Exp. Stn. No. PR 2939.

23. Upadhyaya, H. D., Pundir, R. P. S., Dwivedi, S. L., Gowda, C. L. L., Reddy, V. G., and Singh, S. 2009. Developing a mini core collection of sorghum for diversified utilization of germplasm. Crop Sci. 49:1769-1780. 